\title{
Pharmaceutical films made from the waste material from the preparation of propolis extracts: development and characterization
}

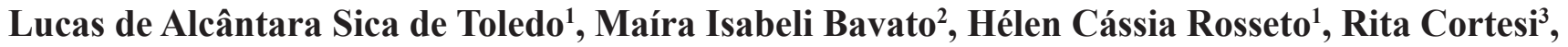 \\ Marcos Luciano Bruschi, ${ }^{1,2 *}$
}

\begin{abstract}
${ }^{1}$ Postgraduate Programme in Pharmaceutical Sciences, ${ }^{2}$ Department of Pharmacy, State University of Maringá, Maringá, Paraná, Brazil, ${ }^{3}$ Department of Life Sciences and Biotechnology, University of Ferrara, Ferrara, Italy
\end{abstract}

\begin{abstract}
This study investigated the development and characterized the physicochemical properties of films obtained from by-products (BP) from the preparation of propolis extracts. Films were produced in the presence and absence of a polymeric adjuvant (gelatin or ethylcellulose) and propylene glycol by a solvent casting method. Density, surface topography by scanning electron microscopy, mechanical properties (folding endurance, tensile strength and percentage elongation), water vapour permeability (WVP), moisture uptake capacity, thermogravimetry, differential scanning calorimetry and Fourier transform infrared spectroscopy (FTIR) were determined. The films were a transparent, light greenishyellow colour, with a uniform surface, and were flexible and easy to handle. The thickness and density of the preparations indicated that the compounds were homogeneously dispersed throughout the film. Mechanical properties were influenced by the film composition; films containing gelatin were more resistant to stress, while those containing ethylcellulose were more flexible. Increasing the adjuvant concentration decreased the elasticity and the rupture resistance, but increased the moisture uptake capacity and WVP of the formulations. BP was thermally stable as were the films. FTIR tests suggested interactions between BP and the adjuvants. This work could contribute to the utilization of BP to prepare films for food and pharmaceutical uses
\end{abstract}

Uniterms: Propolis/byproducts. Propolis/use of waste material/films development. Films/propolis byproducts/physicochemical properties. Polymers. Ethylcellulose. Gelatin.

Este estudo investigou o desenvolvimento e as características físico-químicas de filmes obtidos com o resíduo (BP), normalmente descartado, advindo da preparação de extratos de própolis. Os filmes foram produzidos com e sem adjuvantes poliméricos (gelatina ou etilcelulose) e propilenoglicol, pelo método de evaporação de solvente. Foram determinadas a densidade, a topografia de superfície usando microscopia eletrônica de varredura, as propriedades mecânicas (resistência à dobra, tensão e elongação), transmissão de vapor de água (WVP), capacidade de absorção de umidade, termogravimetria, calorimetria exploratória diferencial e espectroscopia de infravermelho com transformada de Fourier (FTIR). Os filmes demonstraram coloração verde-amarelada, transparência, uniformidade de superfície, homogeneidade, flexibilidade e fácil manuseio. A espessura e a densidade das preparações indicaram que os compostos estavam dispersos de forma homogênea. As propriedades mecânicas foram influenciadas pela composição dos filmes e aqueles que continham gelatina apresentaram-se mais resistentes enquanto os compostos por etilcelulose demonstraram maior flexibilidade. Com o aumento da concentração polimérica, a resistência e a elasticidade diminuíam, porém aumentou a capacidade de absorção de água e a WVP das formulações. $\mathrm{BP}$ apresentou estabilidade térmica assim como os filmes. Os testes de FTIR sugeriram interações entre o BP e os adjuvantes utilizados. Este trabalho pôde contribuir com a utilização de BP na preparação de filmes para uso alimentício e farmacêutico.

Unitermos: Própolis/resíduos. Própolis/resíduos/desenvolvimento de filmes. Filmes/resíduo de própolis/ propriedades físico-químicas. Polímeros. Etilcelulose. Gelatina.

*Correspondence: Dr. Marcos Luciano Bruschi. Departmento de Farmácia. Universidade Estadual de Maringá. Av. Colombo, n. 5790, K68, S05, 87020-900.

Maringa - PR, Brazil. E-mail: mlbruschi@uem.br 


\section{INTRODUCTION}

Biodegradable polymeric films have been used as coating agents, drug delivery platforms, edible films and packing materials in various segments of the pharmaceutical industry. They constitute important materials for tastemasking, moisture-resistance barriers, and drug release control (Carvalho et al., 2010; Steele et al., 2011; Nascimento, Calado, Carvalho, 2012; Santos et al., 2014). In the past several decades, the growing global desire for safer, renewable, and eco-friendly materials has greatly stimulated research activities on natural polymers (Bogdansky, 1990; Soskolone, Freidman, 1996; Yoo, Dharmala, Lee, 2006; Dixit, Puthli, 2009; Thakur, Thakur, 2014). There are many materials in nature capable of forming cohesive and homogeneous films, and they generally fall into the categories of polysaccharides, proteins and lipids (Khazaei et al., 2014). These natural compounds are normally found in vegetables and in products from animal origin.

Propolis (bee glue) is a strongly adhesive resinous compound produced by honeybees and extracted from the beehive. It has a complex chemical composition and typically consists of gums, resins, bee wax, volatile substances, phenol substances, and impurities (Ghisalberti, 1979; Burdock, 1998). It has been utilized by mankind, since ancient times due to its antimicrobial, fungicidal, antiviral, antiulcer, immunostimulating, hypotensive, inflammatory, antioxidant, and cytostatic activities (Burdock, 1998; Isla et al., 2001; Nagai et al., 2001; Bruschi et al., 2003; Marcucci, 2006; Sforcin, Bankova, 2011; Pereira, Bruschi, 2012). The therapeutic properties of propolis are normally attributed to its ethanolic extracts, which can be used as the eventual dosage form or incorporated into foods, beverages, medicines or cosmetics (Burdock, 1998; Bruschi et al., 2003; Avanço, Bruschi, 2008). During the extraction process of propolis constituents, the solvent carries a smaller amount of substances and a greater part is to be dissolved, constituting the residue or (BP) that is not utilized and normally disposed (Bruschi et al., 2002). However, BP possesses in its composition several substances such as wax, resins and gums, which may be important in the development of micro/nanostructured compounds (Bruschi et al., 2003; Hasirci et al., 2011; Sulaiman et al., 2011; Bodini et al., 2013).

Moreover, the high diversity of industrial production methods, and the population and consumption increase around the world has generated great accumulation of waste in several sectors. In order to protect the environment, the reduction of synthetic plastic materials and the use of films obtained from polymers that are able to be fully and quickly reincorporated into nature, must be prioritized (Gómez-Estaca, Montero, Gómez-Guillén, 2014). The use of natural residues has increased as general ecological consciousness and awareness have grown with the implementation of the three Rs concept (reduce, reuse, recycle) (Dowdle, 2005; Larney, Van Aardt, 2010). Agricultural, pharmaceutical, livestock, fishery, and food industries, among others, produce waste products that are rich in biopolymers and display film-forming characteristics (Hernandez-Izquierdo, Krochta, 2008). The utilization of these byproducts is for the exclusive purpose of being environmentally friendly, because they also could be important sources of active compounds such as proteins, enzymes, natural polymers and volatile oils, which are largely responsible for the activity of natural products (Coelho et al., 2001).

Within this context, the aim of this study was to develop and characterize films prepared using the residue discarded from the preparation of propolis extracts. Additionally, the addition of different polymeric adjuvants with distinct water affinities was also evaluated. The films were characterized regarding their water vapour permeability, moisture uptake capacity, and according to their microscopic, chemical, thermal and mechanical characteristics.

\section{MATERIAL AND METHODS}

\section{Material}

Propolis by-product (BP) was obtained from preparation of extracts of Brazilian propolis samples, which were collected from hives of Apis mellifera L. bees. The apiary is located inside a eucalyptus reserve surrounded by native forest with a predominance of Baccharis dracunculifolia (Asteraceae), at the Iguatemi Experimental Farm of the State University of Maringá. This type of propolis is classified as 'type BRP', a typical propolis from the northwest of Paraná state, Brazil (Marcucci, 2006). Type A gelatin (Sigma Aldrich, St. Louis, MO, USA), standard premium ethylcellulose NF 20 (Colorcon, São Paulo, Brazil) and propylene glycol (Synth, São Paulo, Brazil) were used without further purification. Dry potassium bromide (KBr, FT-IR grade) was purchased from Sigma Aldrich, St. Louis, MO, USA). All other chemicals were purchased from Merck (Darmstadt, Germany) or Synth (São Paulo, Brazil) and were of analytical grade.

\section{Residue solubility and film formation}

$\mathrm{BP}$ residue was dispersed in different solvents (water, ethanol 60\%, 77\%, and 96\%, v/v) with stirring 
for $24 \mathrm{~h}$, in a dark and sealed, airtight flask. Afterwards, the dispersions were filtered and $5.0 \mathrm{~g}$ of each extractive solution was concentrated in a water bath $\left(100^{\circ} \mathrm{C}\right)$, with intermittent shaking. The concentrated material was then dried on the Ohaus-MB 200 infrared analytical balance (Pine Brook, NJ, USA) at $110^{\circ} \mathrm{C}$ until a constant weight was achieved. Each extractive solution was carried out in triplicate to estimate the inherent variability of the determination. Moreover, BP extracts were evaluated in terms of film-forming ability by using the solvent evaporation method (Amnuaikit et al., 2005). Briefly, the extractive solutions were stirred, poured onto polyethylene plates and dried under controlled conditions (temperature $=30 \pm 1{ }^{\circ} \mathrm{C}$, relative humidity $=60 \pm 5 \%$ ) for $12 \mathrm{~h}$. The transition between a film- forming dispersion and a nonfilm-forming dispersion was then determined.

\section{Preparation of films}

The BP dispersion (BPD) was prepared with a 50:50 ratio $(\mathrm{w} / \mathrm{w})$ of $\mathrm{BP}$ to ethanol $96^{\circ} \mathrm{GL}$ by turbo extraction (List, Schmidt, 1989), at $3500 \mathrm{rpm}$, for three times for $15 \mathrm{~min}$ with two intervals of $5 \mathrm{~min}$. The preparation was filtered through filter paper, and brought up to the initial weight with ethanol. Exactly $10 \mathrm{~g}$ of solution was weighed and concentrated in a water bath $\left(100^{\circ} \mathrm{C}\right)$ with occasional shaking. The concentrated material was dried on the Ohaus-MB 200 infrared analytical balance (Pine Brook, NJ, USA) at $110^{\circ} \mathrm{C}$ and the final weight was designated as the dryness residue (DR) value. Three replicates were carried out to estimate the inherent variability of each determination.

Gelatin or ethylcellulose was dispersed in water or ethanol 96\% (v/v), respectively. The dispersion of polymeric adjuvant and propylene glycol $(0.5 \%, \mathrm{w} / \mathrm{w})$ was added to BPD at $25^{\circ} \mathrm{C}$, with magnetic agitation for $30 \mathrm{~min}$. The amount of polymeric adjuvant utilized was a function of the DR of BPD (Table I). The final dispersion was poured onto polyethylene moulds and placed in a preheated fan-assisted oven (Nova Ética, São Paulo, Brazil) set at $40{ }^{\circ} \mathrm{C}$ for a period of up to $3.5 \mathrm{~h}$. After drying, the films were removed from the moulds and kept dry until further tests.

\section{Determination of thickness and density}

The thickness of the prepared films was determined using a micrometer. For each film formulation, samples of $1.0 \mathrm{~cm}^{2}$ were measured at five different points (Cao, Yang, Fu, 2009; Deshmane et al., 2009; Nesseem, Eid, El-Houseny, 2011). For density determination, the film
TABLE I - Composition of film formulations

\begin{tabular}{lcccc}
\hline \multirow{2}{*}{ Material } & \multicolumn{4}{c}{ Composition $(\%, w / w)$} \\
\cline { 2 - 5 } & F1 & F2 & F3 & F4 \\
\hline DR of BPD* & 60 & 57.5 & 55 & 52.5 \\
Gelatin & 40 & 42.5 & - & - \\
Ethylcellulose & - & - & 45 & 47.5 \\
\hline
\end{tabular}

$* \mathrm{DR}=$ dryness residue; $\mathrm{BPD}=$ Dispersion of residue of propolis extraction

samples were weighed after drying in a pre-heated fanassisted oven at $40{ }^{\circ} \mathrm{C}$ for $20 \mathrm{~h}$. From these measures, the film's density was calculated according to the equation:

$$
\rho=\mathrm{m} /(\mathrm{A} . \mathrm{h})
$$

where $\rho$ is the density $\left(\mathrm{g} \mathrm{mL}^{-1}\right), \mathrm{m}$ is the mass, $\mathrm{A}$ is the surface area $\left(\mathrm{mm}^{2}\right)$ and $\mathrm{h}$ is the thickness $(\mathrm{mm})$ of the film sample. At least four replicates were carried out to estimate the inherent variability of each determination.

\section{Scanning electron microscopy}

The surface topography of the films was studied under a scanning electron microscope (Shimadzu - SS550, Tokyo, Japan). Samples were mounted on stubs and coated with colloidal gold under an argon atmosphere, using a sputter coater. The scanning electron micrographs (SEM) were obtained and analyzed.

\section{Mechanical tests}

\section{Folding endurance}

The folding endurance of each formulation was evaluated by repeatedly folding the film at the same place until it broke or folded up to 300 times manually, which was considered satisfactory to reveal good film properties (Deshmane et al., 2009). The number of times a film could be folded without breaking gave the value of the folding endurance. This test was done on three randomly selected samples of each preparation.

\section{Tensile tests}

Tensile testing of films was performed using a TAXTplus Texture Analyzer (Stable Micro Systems, Surrey, United Kingdom) at $25 \pm 1{ }^{\circ} \mathrm{C}$ and $50 \pm 10 \%$ relative humidity (ASTM, 2012). Six film strips (50 x $10 \mathrm{~mm})$ were cut from each formulation and mounted between the grips, spaced $20 \mathrm{~mm}$ apart. The cross-head speed was $2 \mathrm{~mm} \mathrm{~s}^{-1}$. The thickness of the film had to fall within $\pm 0.25 \mathrm{~mm}$ of 
the average to be acceptable for testing. Stress-strain data were collected by a microcomputer and used to determine the tensile strength $\left(\mathrm{T}, \mathrm{N} \mathrm{mm}^{-2}\right)$ and percent elongation $\left(\mathrm{E}, \% \mathrm{~mm}^{2}\right)$ at the break point, according to the equations (Yang, Paulson, 2000):

$$
\begin{gathered}
\mathrm{T}=\mathrm{F} / \mathrm{A} \\
\mathrm{E}=(\Delta \mathrm{L} \cdot 100) /(\mathrm{L} \cdot \mathrm{A})
\end{gathered}
$$

where $\mathrm{F}$ is the force at the break point $(\mathrm{N})$, $\mathrm{A}$ is the cross-sectional area $\left(\mathrm{mm}^{2}\right)$, L is the initial length of the sample, and $\Delta \mathrm{L}$ is the length the patch increased $(\mathrm{mm})$.

\section{Water vapour permeability}

A film of appropriate dimensions was mounted on a permeation cell containing $10 \mathrm{~mL}$ of purified water. The charged cells were weighed and placed in pre-equilibrated desiccators maintained at $0 \%$ relative humidity and $25^{\circ} \mathrm{C}$. The cells were reweighed after 1,2, 3, 4 and 5 days. The amount of water transmitted through the film was revealed by the weight loss of the assembled cell. The water vapour permeability (WVP, $\mathrm{g} \mathrm{d}^{-1} \mathrm{~mm}^{-2}$ ) was calculated using the equation (Kanig, Goodman, 1962):

$$
\mathrm{WVP}=\mathrm{m} /(\mathrm{t} . \mathrm{A})
$$

where $\mathrm{m}$ is the permeated water weight $(\mathrm{g}), \mathrm{t}$ is the time (days) and A the area of the film $\left(\mathrm{mm}^{2}\right)$. The analyses were carried out at least in triplicate to estimate the inherent variability of each determination.

\section{Moisture uptake capacity}

Film samples (size $100 \mathrm{~mm}^{2}$ ) were dried in a fanassisted oven, at $40{ }^{\circ} \mathrm{C}$ for $20 \mathrm{~h}$. The dried formulations were weighed, and immediately submerged in purified water. The excess water was removed and the samples were weighed again. This procedure was repeated at predetermined time intervals $(1,10,30,6075,90,105$ and $120 \mathrm{~min}$ ). The following equation was used to calculate the moisture uptake capacity at each time interval (Amnuaikit et al., 2005; Nesseem, Eid, El-Houseny, 2011):

$$
\operatorname{MUC}(\%)=\left[\left(\mathrm{W}_{\mathrm{s}}-\mathrm{W}_{\mathrm{d}}\right) \cdot 100\right] / \mathrm{W}_{\mathrm{d}}
$$

where $\mathrm{W}_{\mathrm{s}}$ is the swelled film weight and $\mathrm{W}_{\mathrm{d}}$ is the dried film weight. The analyses were carried out at least in triplicate to estimate the inherent variability of each determination.

\section{Thermal analysis}

Thermogravimetry (TG) and differential scanning calorimetry (DSC) techniques were accomplished using a thermogravimetric analyzer model Q 50 and a differential scanning calorimeter model Auto Q20 (TA Instruments, New Castle, DE, USA), respectively. Samples of 5.0 $\pm 0.1 \mathrm{mg}$ were cut into small pieces and placed into a hermetically sealed DSC sample platinum pan. The reference was an empty pan. Both sample and reference pans were submitted to a heating scan rate of $10^{\circ} \mathrm{C} \mathrm{min}{ }^{-1}$, from $20^{\circ} \mathrm{C}$ to $300^{\circ} \mathrm{C}$, under a constant flow of argon gas $\left(30 \mathrm{~mL} \mathrm{~min}^{-1}\right)($ El-Kamel, Ashri, Alsarra, 2007; Villa Nova et al., 2013). In addition, propolis, BP and the polymeric adjuvants (gelatin and ethylcellulose) were also analyzed.

\section{Fourier-transform infrared spectroscopy (FT-IR)}

A $2.5 \%(\mathrm{w} / \mathrm{w})$ mixture of sample in dry $\mathrm{KBr}$ was prepared. The mixture was ground into a fine powder using a mortar and compressed into a disc under a pressure of $10 \mathrm{~kg} \mathrm{~cm}^{-2}$. Each disc was analyzed at a resolution of $4 \mathrm{~cm}^{-1}$ over a wave number region of $400-4000 \mathrm{~cm}^{-1}$ using an FT-IR spectrometer (Spectrum Lambda 19 FTIR system, Perkin Elmer, USA). The characteristic peaks of IR transmission spectra were recorded. Each film formulation was tested at least in triplicate (Nesseem, Eid, El-Houseny, 2011; Anuar et al., 2007).

\section{Statistical analysis}

The data from each determination were presented as the mean and standard deviation (mean $\pm \mathrm{SD}$ ). The paired Student's $t$-test was used to determine the difference in the capacity of each solvent to dissolve the BP. In all tests, a value of $p<0.05$ was taken to denote significance (Jones, 2002), and Statistica 8.0 software (StatSoft Company, Tulsa, Oklahoma) was used throughout.

\section{RESULTS}

\section{Residue solubility and film formation}

The BP residue was more soluble in ethanolic solvents than in purified water (Table II). The difference in solubility between the ethanol extractions was not significant. Therefore, BP showed a greater ethanol affinity when compared with water, denoting a similarity between BP and propolis (Bruschi et al., 2003; Bruschi et al., 2006).

In addition, the BP residue was evaluated regarding its film-forming ability. BPDs containing lower 
TABLE II - Solubility in different solvents of residue obtained from preparation of propolis extracts $(\mathrm{BP})$

\begin{tabular}{lc}
\hline Solvent & Soluble fraction $(\%, \mathrm{w} / \mathrm{w})$ \\
\hline Purified water & $2.512 \pm 0.308$ \\
Ethanol $60 \%(\mathrm{v} / \mathrm{v})$ & $3.592 \pm 0.073$ \\
Ethanol $77 \%(\mathrm{v} / \mathrm{v})$ & $3.668 \pm 0.042$ \\
Ethanol $96 \%(\mathrm{v} / \mathrm{v})$ & $3.635 \pm 0.764$ \\
\hline
\end{tabular}

concentrations of ethanol ( 60 and $77 \%, \mathrm{v} / \mathrm{v})$ did not result in films with good characteristics. However, the BPD prepared using ethanol $96 \%(\mathrm{v} / \mathrm{v})$ yielded film with good characteristics in terms of homogeneity, uniformity of product and low adhesion to the moulds. Considering these results and the high content of resins in BP, the chosen solvent was ethanol 96\% (v/v). Notwithstanding the characteristics of the obtained film, the need to increase its resistance and the need to decrease the tack and thereby facilitate the film removal from the moulds was noted. Therefore, the addition of a polymeric adjuvant (gelatin or ethylcellulose) was considered. These polymers display different solubility in water and are used in preparations containing propolis (Bruschi et al., 2003; Avanço, Bruschi, 2008).

\section{Film thickness and density}

The films displayed a light greenish-yellow color and were transparent, homogeneous, flexible and easily handled. The thickness and densities of the prepared films are shown in Table III. The thickness and mass of the films were used to calculate their density. It was observed that an increase in the polymeric adjuvant content reduced the film density (F2 and F4).

\section{Scanning electron microscopy}

Figure 1 shows SEM micrographs of the prepared films. The preparations were observed to have a uniform
TABLE III - Physicochemical characteristics of films

\begin{tabular}{lcc}
\hline Formulations & $\begin{array}{c}\text { Thickness } \\
\left(10^{-3} \mathrm{~cm}\right)\end{array}$ & $\begin{array}{c}\text { Density } \\
\left(10^{-3} \mathrm{~g} \mathrm{~mL}^{-1}\right)\end{array}$ \\
\hline F1 & $10.75 \pm 0.0001$ & $1.152 \pm 0.186$ \\
F2 & $11.00 \pm 0.0001$ & $0.988 \pm 0.188$ \\
F3 & $10.75 \pm 0.0001$ & $1.009 \pm 0.136$ \\
F4 & $11.00 \pm 0.0001$ & $0.847 \pm 0.121$ \\
\hline
\end{tabular}
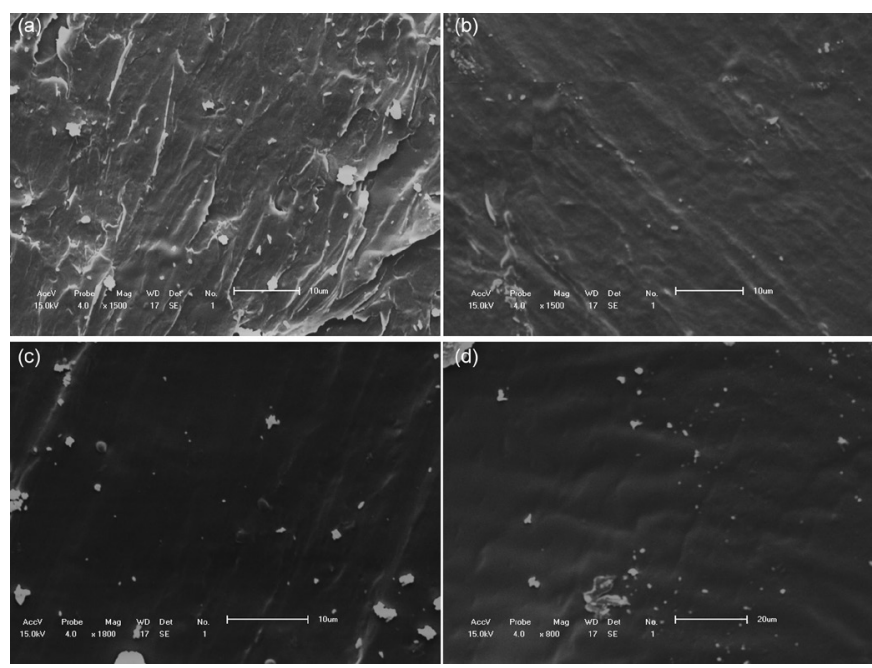

FIGURE 1 - Scanning electron micrographs of the films: (a) F1 (x1500x); (b) F2 (x1500); (c) F3 (x1800); (d) F4 (x800).

surface, without failure and with differences dependent on the polymeric composition.

\section{Mechanical properties}

The results of mechanical analysis of the films are presented in Table IV. The folding endurance analysis showed that it was possible to fold the films containing ethylcellulose (F3 and F4) more than 300 times without breakage. On the other hand, the films containing gelatin (F1 and F2; higher concentrations of BP) displayed a folding endurance of less than 35 times. The composition

TABLE IV - Mechanical properties of films

\begin{tabular}{lccc}
\hline Formulations & \multicolumn{3}{c}{ Properties } \\
\cline { 2 - 4 } & $\begin{array}{c}\text { Tension } \\
\left(\mathrm{N} \mathrm{mm}^{-2}\right)\end{array}$ & $\begin{array}{c}\text { Elongation } \\
\left(\% \mathrm{~mm}^{-2}\right)\end{array}$ & $\begin{array}{c}\text { Folding Endurance } \\
\text { (times) }\end{array}$ \\
\hline F1 & $5.725 \pm 0.009$ & $0.953 \pm 0.002$ & $33.333 \pm 1.528$ \\
F2 & $3.302 \pm 0.080$ & $0.458 \pm 0.010$ & $19.000 \pm 1.732$ \\
F3 & $2.696 \pm 0.067$ & $18.217 \pm 0.389$ & $>300$ \\
F4 & $1.924 \pm 0.074$ & $13.261 \pm 0.649$ & $>300$ \\
\hline
\end{tabular}


of each formulation also influenced its mechanical properties, where the films containing ethylcellulose (lower concentrations of BP) were more flexible. The $\mathrm{F} 1$ film required the largest tension to rupture $(5.725$ $\left.\pm 0.009 \mathrm{~N} \mathrm{~mm}^{-2}\right)$. F4 was the least resistant to rupture $\left(1.924 \pm 0.074 \mathrm{~N} \mathrm{~mm}^{-2}\right)$. Moreover, F3 showed the highest elongation percentage $\left(18.217 \pm 0.389 \% \mathrm{~mm}^{-2}\right)$.

\section{Water vapour permeability and moisture uptake capacity}

The water vapour permeability of formulations, as a function of composition and time, varied from 2.731 to $10.434 \times 10^{-8} \mathrm{~g} \mathrm{~d}^{-1} \mathrm{~mm}^{-2}$ (Figure 2). The highest water permeation was displayed by F2. In contrast, the lowest water vapour permeability was observed for the F1 preparation, most of the time.

Figure 3 shows the moisture uptake capacity of the film over a $120 \mathrm{~min}$ period. Different film affinities to water were observed depending on their composition. Particularly, the lowest index was observed for F3. In contrast, F2 displayed the highest MUC value.

\section{Thermal analysis}

Figure 4 shows the TG curves obtained from different film formulations, pure gelatin, ethylcellulose, $\mathrm{BP}$ and propolis. BP and propolis demonstrated related thermal curves. As the temperature change from 20 to 300 ${ }^{\circ} \mathrm{C}$, the weight loss was 25 and $30 \%$ for BP and propolis, respectively. The results suggest that these materials present very similar characteristics. The main weight

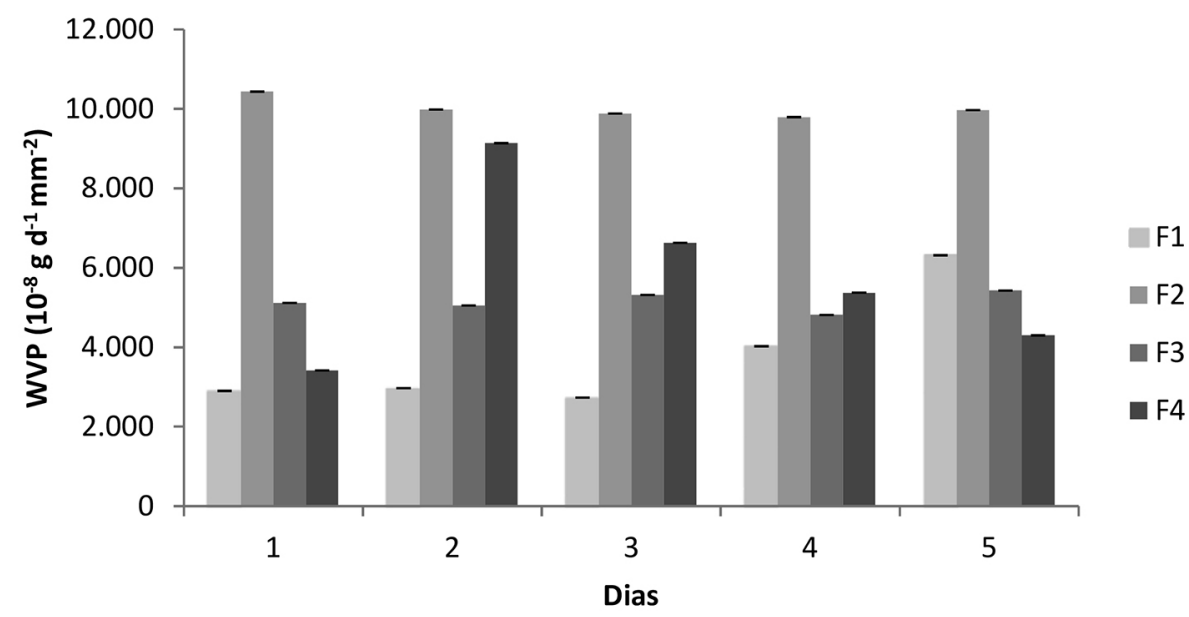

FIGURE 2 - Water vapor permeability (WVP) of films, as a function of time. Error bars are standard deviation of the mean of, at least, three measurements. Where error bars are not visible, they are less than the line thickness.

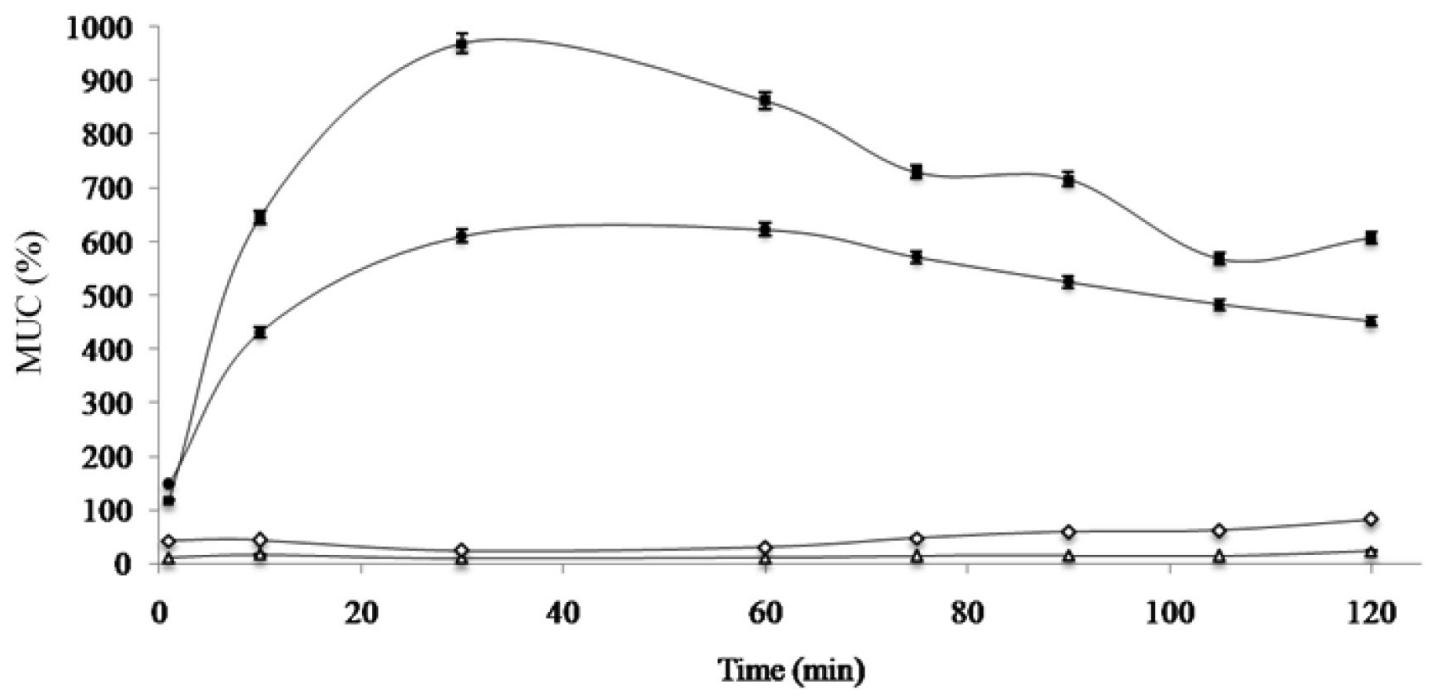

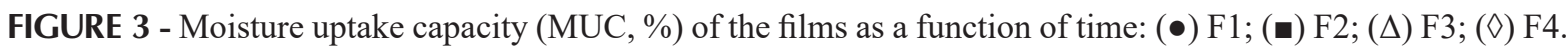



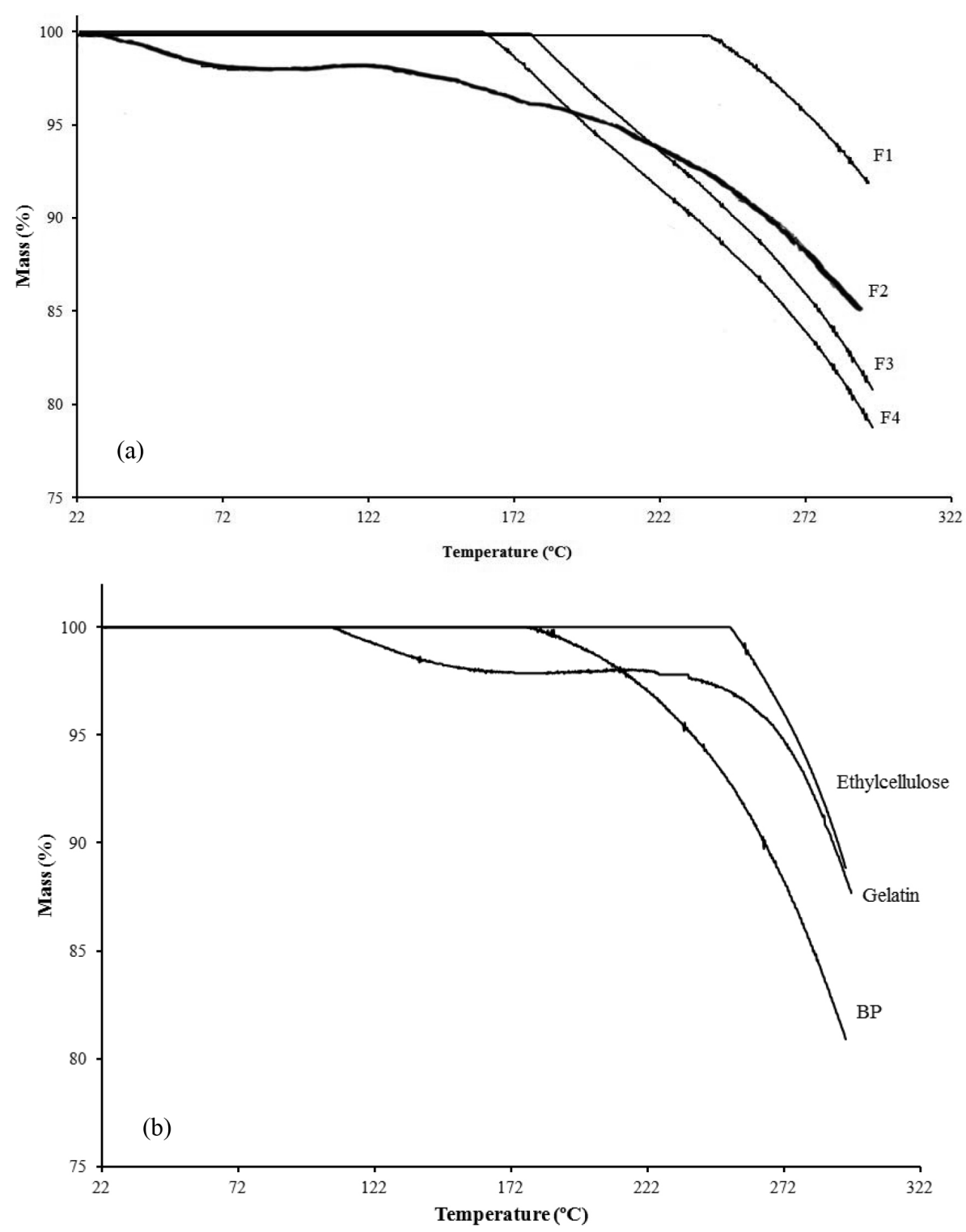

FIGURE 4 - Thermogravimetric curves of: (a) films F1, F2, F3, and F4; (b) ethylcellulose, gelatin, and byproduct (BP).

loss for both materials was observed around $150{ }^{\circ} \mathrm{C}$. Gelatin displayed an initial weight loss $(8 \%)$ in the range of $25^{\circ} \mathrm{C}-160{ }^{\circ} \mathrm{C}$ due to the loss of structural water and the conformational transition of molecules. Another decrease initiated at approximately $270{ }^{\circ} \mathrm{C}$, in which the residual weight was $80 \%$ of the initial, which corresponds to the thermal degradation of the polymeric chains of gelatin (Santos, 2014). The thermal decomposition of films containing gelatin (F1 and F2) occurred in two steps: between 75 and $80^{\circ} \mathrm{C}$, where the weight loss was about $2 \%$, and the other at $150{ }^{\circ} \mathrm{C}$, in which the weight percentage decreased to approximately $85 \%$ of initial. Moreover, ethylcellulose showed thermal decomposition at $200{ }^{\circ} \mathrm{C}$, in which the weight loss was about $15 \%$. Films containing this polymeric adjuvant (F3 and F4) displayed similar thermal decomposition around $150{ }^{\circ} \mathrm{C}$ with $20 \%$ weight loss.

Analyzing the DSC curves shown in Figure 5, it was observed that the curves of BP and propolis (Figures $5 \mathrm{~g}$ and $5 \mathrm{~h}$ ) have an endothermic peak around $75^{\circ} \mathrm{C}$. The DSC curve of pure gelatin (Figure 5f) has endothermic peak temperature at $75^{\circ} \mathrm{C}$ and again after $225^{\circ} \mathrm{C}$, the same temperature at which a loss of mass was observed in the TG curve that characterized the onset of gelatin decomposition. In the thermal curves for films containing gelatin (Figures $5 \mathrm{~d}$ and $5 \mathrm{e}$ ), the endothermic peaks are not present. The ethylcellulose DSC curve displayed an endothermic peak temperature at approximately $200{ }^{\circ} \mathrm{C}$, corroborating with the TG result. Moreover, the films containing this polymeric adjuvant showed a similar 


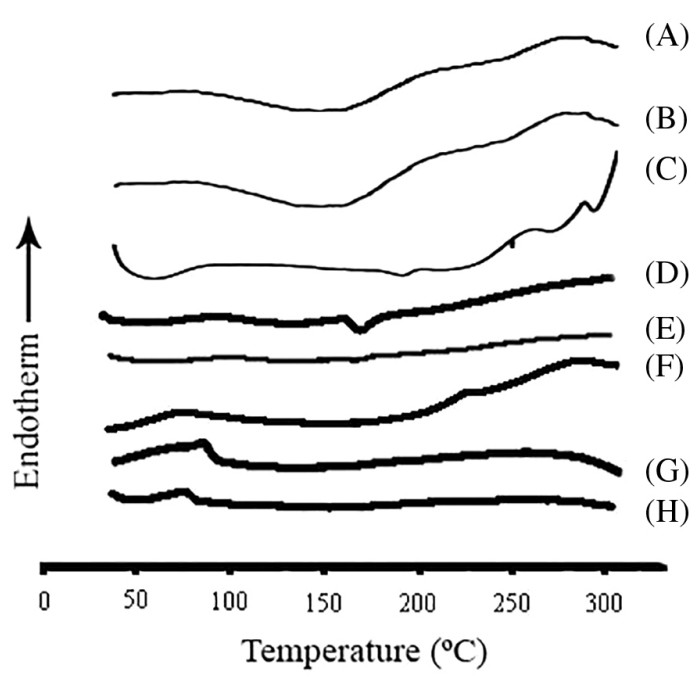

FIGURE 5 - Differential scanning calorimetric curves of: (A) F4; (B) F3; (C) ethylcellulose; (D) F2; (E) F1; (F) gelatin; (G) $\mathrm{BP} ; \mathrm{H})$ propolis. "The aim of the Figure is show the differences between the curves of the materials, the scale (units) were not shown.

endothermic peak around $150^{\circ} \mathrm{C}$, the same temperature range at which a mass loss was observed in the TG curves.

\section{FT-IR spectroscopy}

The FT-IR spectra of BP and propolis are displayed in Figure 6. A great similarity is observed between them, mainly when the peaks at $3300,2917,2849,1735,1630$, $1530,1462,1376,1265,1196,1172$, and $1030 \mathrm{~cm}^{-1}$ are analyzed. There is also a peak on the BP spectrum near the region of $1084 \mathrm{~cm}^{-1}$, which could be due to some ethanol residue (Silverstein, Webster, Kiemle, 2005).

Figure 7 shows the FT-IR spectra of the films and the pure polymeric adjuvants. Similarity between the film composition was also observed when the FT-IR results were analyzed. Some bands observed in the BP spectrum are present on the films' spectrums, showing that many of their characteristics are from BP. There is a band around $1050 \mathrm{~cm}^{-}$ ${ }^{1}$, for the films containing ethylcellulose that is not present for the films containing gelatin. This band is characteristic of C-H bonds (Silverstein, Webster, Kiemle, 2005).

\section{DISCUSSION}

The polymers employed in this research were chosen due to their different affinity for water, gelatin being the hydrophilic adjuvant while ethylcellulose was the hydrophobic adjuvant. The concentrations used for each of the polymeric materials were different because they were prepared with the least quantity necessary to form a film that could be removed from the mould and also presented macroscopic homogeneity and the absence of air bubbles.

Films made of gelatin or hydroxypropylmethyl

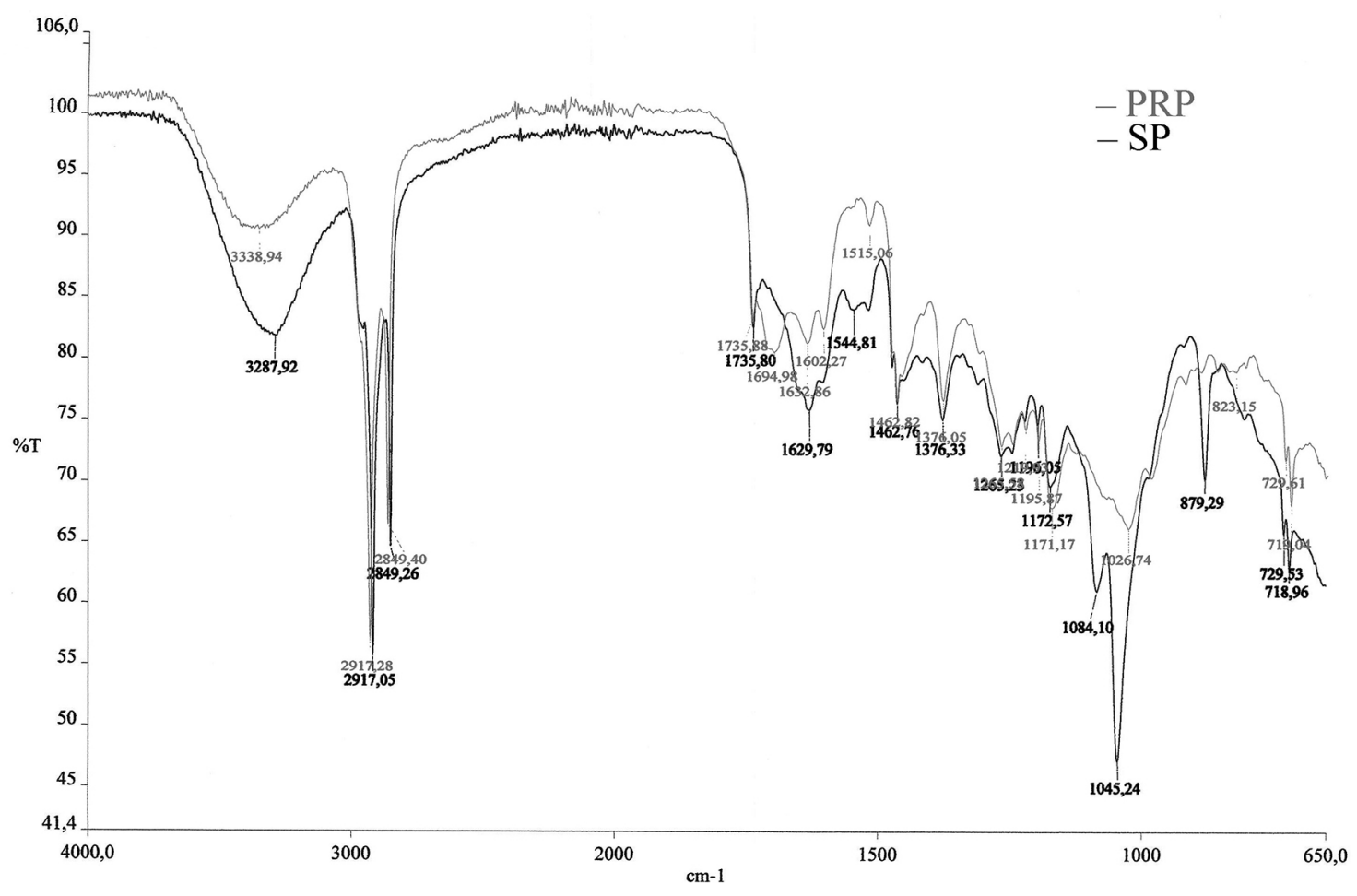

FIGURE 6 - Fourier transform infrared (FT-IR) spectra of propolis (PRP) and the residue BP. 


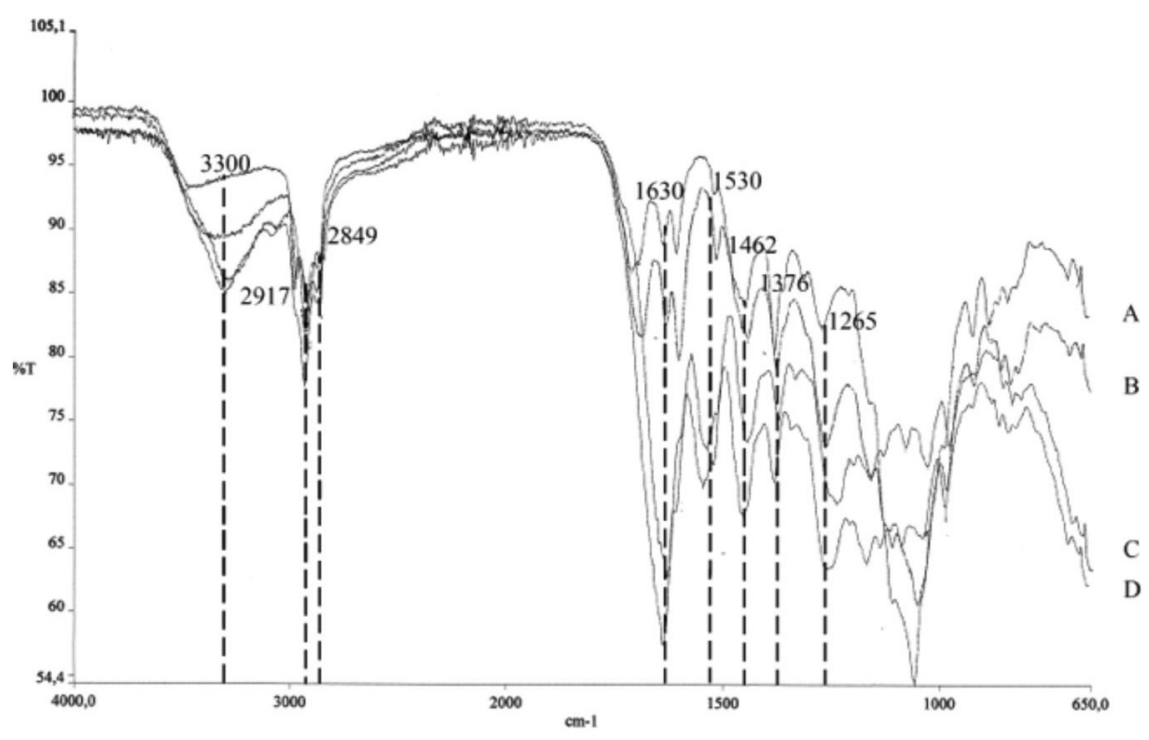

FIGURE 7 - Fourier transform infrared (FT-IR) specta of films: (a) F3; (b) F4; (c) F2; (d) F1.

cellulose containing propolis extract as a therapeutic agent have already been proposed, showing that propolis incorporation enables the obtainment of polymeric films with physical and mechanical properties, dependent on the extract concentration used (Bodini et al., 2013; Rowe, Sheskey, Quinn, 2009). These observed film properties are mainly due to the polymer characteristics and to the presence of resins, gums, waxes, proteins, minerals and other chemicals in the propolis extract. Considering that the BP extract is a material resulting from the second propolis extraction, the substances described above are still present in this waste material, but in different proportions (Figure 7), which may allow an improvement in the film-forming properties.

Therefore BP films could represent a new alternative for the production of safer and more effective pharmaceutical products. Moreover, the use of a normally discarded residue is environmental friendly and adds value to propolis. Use of BP to prepare films could not be found in the current literature, constituting a new purpose. Moreover, the presence of resins, gums, waxes, proteins, minerals and other chemical constituents contribute to the film-forming ability of BP, as observed in the propolis (Bruschi et al., 2003).

The process of obtaining BP extract is very similar to the one employed to prepare propolis extract and likely would not lead to the formation of toxic compounds (Burdock, 1998). In this context, the ethanolic extract of BP, prepared with ethanol $96 \%$ (v/v) displayed good film-forming ability.

However, a need to decrease the tack and increase the resistance of films was observed. Therefore, a plasticizer (propylene glycol) and polymeric adjuvants were added. Propylene glycol is a commonly used plasticizer in polymeric films (Rowe, Sheskey, Quinn, 2009). The presence of a plasticizer is of importance since it strongly affects the film's physicochemical properties. The addition of a plasticizer leads to a decrease in intermolecular forces along polymer chains, which enhances the flexibility, decreases brittleness, and makes it easier for the film to be peeled off the mould (Nesseem, Eid, El-Houseny, 2011). The polymers gelatin and ethylcellulose were used as adjuvants to investigate the film-forming behaviour of BP, and the characteristics of the obtained films, in the presence of polymers with different affinities for water.

In order to assess the properties of the obtained films, it is necessary to study their physical and chemical characteristics. The thickness of the prepared films was measured to ensure that the materials were distributed evenly throughout the sample. For all film compositions, the mean sample thickness was between 107.5 and 110 $\mu \mathrm{m}$. No film demonstrated a large variation in thickness or a non-homogeneous structure, indicating that the plasticizer and adjuvant were homogeneously dispersed into BPD. The samples were easily cut into the proper dimensions required for the analyses, indicating that the films did not show brittleness or a lack of plasticity. The film containing the highest amount of ethylcellulose (F4) displayed a more uniform surface (Figure 1). Moreover, the surface topography of the samples was different on each side. The surface in contact with the mould showed smooth characteristics and the side facing the air displayed surface characteristics related to solvent evaporation. 
A relationship was observed between the differences in density and composition, as there was no great variation in the samples' volume (surface area and thickness). The density of ethyl cellulose is $1.14 \mathrm{~g} \mathrm{~mL}^{-1}$, while gelatine possesses a density of $1.32 \mathrm{~g} \mathrm{~mL}^{-1}$ (Rowe, Sheskey, Quinn, 2009). Therefore, the films containing gelatine (F1 and F2) displayed higher densities. Moreover, the films containing the lower adjuvant amount (F1 and F3) showed the highest density values. Thus, BP contributes to a greater density than do the two polymeric adjuvants.

The investigation of the mechanical properties of films are useful to assess the basic film-forming properties of new materials, thereby predicting their usefulness for pharmaceutical utilization, e.g. coating and drug delivery (Satturwar et al., 2002). The presence of adjuvant decreased the intermolecular forces along the chains inside BP, which makes it easier for film to be peeled off of the mould. However, an increase in the amount of polymeric adjuvant decreased the rupture resistance and the elasticity of the films. The presence of gelatin and higher concentrations of $\mathrm{BP}$ rendered films harder and less resistant to folding. The presence of ethyl cellulose (lowest amount of BP) provided flexibility to the films. Gelatin films have displayed good rupture resistance, but the presence of propolis extract decreased the tensile strength of these films (Bodini et al., 2013). Conversely, in this study, the films are made of BP with gelatin as an adjuvant (lower amount) and the behaviour of the resulting film was different. An increase in the proportion of gelatin caused a reduction of interaction between the molecules of BP, hence the lower stress obtained for film F2 (Table IV). The decrease in stress could be due to a reduction of intermolecular attraction inside the BP network. In addition, this reduction could have been higher in the presence of ethyl cellulose, which conveyed a greater increase in the flexibility of the films.

The presence of adjuvants influenced the water uptake of the formulations. In the presence of water, there was a rapid polymeric chain relaxation, which was confirmed by the moisture uptake capacity test. F2 displayed the highest MUC and water vapour permeation. In contrast, F1 displayed the lowest values, which may be explained by the highest BP concentration in this film. Propolis is a material utilized by bees to protect the comb from humidity and it was observed that the addition of propolis extract to gelatin films contributed to a significant reduction of the water vapour permeation (Bodini et al., 2013). The formulations containing gelatine demonstrated higher moisture uptake capacity due to greater water solubility. Besides, the films containing the lowest concentration of each polymer (F1 and F3) presented lower MUC than the other ones containing more polymeric adjuvant (F2 and F4). Therefore, the substances contained in BP, and not the adjuvants, are responsible for the reduction in water uptake and the water vapour transmission of films.

For films, thermal analysis may be performed to verify possible interactions between BP and adjuvants, to determine the kinetics of degradation and physical and chemical stability of the formulation components (Wendlandt, 1985). With TG analysis, it could be proven that, albeit a complex compound, BP and the propolis are relatively thermally stable, since they does not begin to decompose until they reache temperatures above $75^{\circ} \mathrm{C}$ (mainly above $150^{\circ} \mathrm{C}$ ). Moreover, small differences were observed between the thermal curves of BP and films in the TG and DSC analyses. The differences were dependent on the type and amount of adjuvant added, which suggests that gelatin and ethyl cellulose were dispersed by BP.

Similarly, with FT-IR spectra of BP and films, an attempt was made to identify the eventual existence of interactions between the polymeric adjuvant and the BP. In the FT-IR results of the films containing gelatin (Figure 7c and $7 \mathrm{~d}$ ), the characteristic peaks observed are very similar to those of BP, suggesting possible interactions between the BP and the adjuvant. On the other hand, comparing the FT-IR spectra of the films containing ethyl cellulose (Figure $7 \mathrm{a}$ and $7 \mathrm{~b}$ ) with that of BP (Figure 6), verified that the characteristic peaks of BP and ethyl cellulose could be seen in the films' spectra. This could explain why the films containing ethyl cellulose were more malleable. The simple $\mathrm{C}-\mathrm{H}$ bonds observed are more flexible and present smaller steric hindrance effects than the more complex bonds, such as those observed for gelatin $(\mathrm{C}=\mathrm{O} ; \mathrm{C}-\mathrm{N}$; C-O; etc.) (Silverstein, Webster, Kiemle, 2005).

\section{CONCLUSION}

For the first time, films could be successfully obtained using the residue obtained from the preparation of propolis extracts, which is normally discarded. Density, water vapour permeability, moisture uptake capacity and the mechanical properties of the films were adversely affected by the addition of polymeric adjuvants with different affinities for water. The thermal stability of films was observed and using the technique of FT-IR, it was proven that while the adjuvant played a role, $\mathrm{BP}$ is the main component responsible for the characteristics of the films. Therefore, considering the results obtained and the principle of sustainability (reduce, reuse and recycle), this work could contribute to the utilization of BP to obtain films for use in the food and pharmaceutical industries. However, further research is needed to gain a 
better understanding of the properties and applications of these films.

\section{ACKNOWLEDGMENT}

The authors are grateful to CNPq (Conselho Nacional de Pesquisa/National Research Council), CAPES (Coordenação de Aperfeiçoamento de Pessoal de Nivel Superior/Coordination for the Improvement of Higher Education), and FINEP (Financiadora de Estudos e Projetos/Financier of Studies and Projects) for their financial support.

\section{DECLARATION OF INTEREST}

The authors report no conflicts of interest.

\section{REFERENCES}

AMNUAIKIT, C.; IKEUCHI, I.; OGAWARA, K.I.; HIGAKI, K.; KIMURA, T. Skin permeation of propranolol from polymeric film containing terpene enhancers for transdermal use. Int. J. Pharm., v.289, n.1-2, p.167-178, 2005.

ANUAR, N.K.; WUI, W.T.; GHODGAONKAR, D.K.; TAIB, M.N. Characterization of hydroxypropylmethylcellulose films using microwave non-destructive testing technique. J. Pharm. Biomed. Anal., v.43, n.2, p.549-557, 2007.

ASTM D882-12. Annual book of ASTM standards. Philadelphia: American Society for Testing \& Materials, 2012. p.1-12.

AVANÇO, G.B.; BRUSCHI, M.L. Preparation and characterisation of ethylcellulose microparticles containing propolis. Pharm. Dev. Technol., v.29, n.2, p.129-135, 2008.

BODINI, R.B.; SOBRAL, P.J.A.; FAVARO-TRINDADE, C.S.; CARVALHO, R.A. Properties of gelatin-based films with added ethanol-propolis extract. Food. Sci. Technol., v.41, n.1, p.104-110, 2013.

BOGDANSKY, S. Natural polymers as drug delivery systems. In: CHASIN, M.; LANGER, R. (Ed.). Biodegradable polymers as drug delivery systems. New York: Marcel Dekker, 1990. p.231-260.

BRUSCHI, M.L.; CARDOSO, M.L.C.; LUCCHESI, M.B.; GREMIÃO, M.P.D. Gelatin microparticles containing propolis obtained by spray-drying technique: preparation and characterization. Int. J. Pharm., v.264, n.1-2, p.45-55, 2003.
BRUSCHI, M.L.; KLEIN, T.; LOPES, R.S.; FRANCO, S.L.; GREMIÃO, M.P.D. Contribuicão ao protocolo de controle de qualidade da própolis e de seus extratos. Rev. Bras. Ciênc. Farm., v.23, n.2, p.289-306, 2002.

BRUSCHI, M.L.; PANZERI, H.; FREITAS, O.; LARA, E.H.G.; GREMIÃO, M.P.D. Sistemas de liberação de fármaco intrabolsa periodontal. Rev. Bras. Ciênc. Farm., v.42, n.1, p.29-47, 2006.

BURDOCK, G.A. Review of the biological properties and toxicity of bee propolis (Propolis). Food Chem. Toxicol., v.36, n.4, p.347-363, 1998.

CAO, N.; YANG, X.; FU, Y. Effects of various plasticizers on mechanical and water vapor barrier properties of gelatin films. Food Hydrocol., v.23, n.3, p.729-735, 2009.

CARVALHO, F.C.; BRUSCHI, M.L.; EVANGELISTA, R.C.; GREMIÃO, M.P.D. Mucoadhesive drug delivery systems. Bras. J. Pharm. Sci., v.46, n.4, p.381-387, 2010.

COELHO, M.A.Z.; LEITE, S.G.F.; ROSA, M.F.; FURTADO, A.A.L. Aproveitamento de resíduos agroindustriais: produção de enzimas a partir da casca de coco verde. Boletim CPPA, v.19, p.33-42, 2001.

DESHMANE, S.; CHANNAWAR, M.; CHANDEWAR, A.; JOSHI, U.; BIYANI, K. Chitosan based sustained release mucoadhesive buccal patches containing verapamil HCL. Int. J. Pharm. Pharm. Sci., v.1, p.216-229, 2009.

DIXIT, R.P.; PUTHLI, S.P. Oral strip technology: overview and future potential. J. Control. Release, v.139, n.2, p.94-107, 2009.

DOWDLE, H. Recycling in style. Natural Health, p.35-36, 2005.

EL-KAMEL, A.H.; ASHRI, L.Y.; ALSARRA, I.A. Micromatricial metronidazole benzoate film as a local mucoadhesive delivery system for treatment of periodontal diseases. AAPS Pharm. Sci. Tech., v.8, n.3, p.E1-E11, 2007.

GHISALBERTI, E.L. Própolis: a review. Bee World, v.60, p.59-80, 1979.

GÓMEZ-ESTACA, J.; MONTERO, P.; GÓMEZ-GUILLÉN, M.C. Shrimp (Litopenaeus vannamei) muscle proteins as source to develop edible films. Food Hydrocol., v.41, p.86-94, 2014. 
HASIRCI, V.; YILGOR, P.; ENDOGAN, T.; EKE, G.; HASIRCI, N. Polymer fundamentals: polymer synthesis. Comprehensive biomaterials. Amsterdam: Elsevier North Holland, 2011. 3672 p.

HERNANDEZ-IZQUIERDO, V.M.; KROCHTA, J.M. Thermoplastic processing of proteins for film formation: a review. J. Food Sci., v.73, n.2, p.R30-R39, 2008.

ISLA, M.I.; MORENO, M.I.N.; SAMPIETRO, A.R.; VATTUONE, M.A. Antioxidant activity of argentine propolis extracts. J. Ethnopharmacol., v.75, n.2, p.165$170,2001$.

JONES, D.S. Pharmaceutical statistics. London: The Pharmaceutical Press, 2002. 586 p.

KANIG, J.L.; GOODMAN, H. Evaluative procedures for filmforming materials used in pharmaceutical applications. $J$. Pharm. Sci., v.51, n.1, p.77-83, 1962.

KHAZAEI, N.; ESMAILI, M.; DJOMEH, Z.E.; GHASEMLOU, M.; JOUKI, M. Characterization of new biodegradable edible film made from basilseed (Ocimum basilicum L.) gum. Carbohydr. Polym., v.102, p.199-206, 2014.

LARNEY, M.; VAN AARDT, A.M. Case study: apparel industry waste management: a focus on recycling in South Africa. Waste Manag. Res., v.28, n.1, p.36-42, 2010.

LIST, P.H.; SCHMIDT, P.C. Phytopharmaceutical technology. Londres: Heyden \& Son, 1989. p.112-115.

MARCUCCI, M.C. Classified propolis: a new way to produce medicines from natural sources, containing this bee product. Rev. Fitos, v.1, n.3, p.36-46, 2006.

NAGAI, T.; SAKAI, M.; INOUE, R.; INOUE, H.; SUZUKI, $\mathrm{N}$. Antioxidative activities of some commercially honeys, royal jelley, and propolis. Food Chem., v.75, n.2, p.237$240,2001$.

NASCIMENTO, T.A.; CALADO, V.; CARVALHO, C.W.P. Development and characterization of flexible film based on starch and passion fruit mesocarp flour with nanoparticles. Food. Res. Int., v.49, n.1, p.588-595, 2012.

NESSEEM, D.I.; EID, S.F.; EL-HOUSENY, S.S. Development of novel transdermal self- adhesive films for tenoxicam, an anti-inflammatory drug. Life Sci., v.89, p.430-438, 2011.
PEREIRA, R.R.A.; BRUSCHI, M.L. Preparation and characterization of mucoadhesive thermoresponsive systems containing propolis for the treatment of vulvovaginal candidiasis. J. Pharm. Res., v.102, n.4, p.1222-1234, 2012.

ROWE, C.R.; SHESKEY, P.J.; QUINN, M.E. Handbook of pharmaceutical excipients. 6.ed. Londres: Pharmaceutical Press, 2009. 855 p.

SANTOS, T.M.; SOUZA, M.S.M.F.; CACERE, C.A.; ROSA, M.F.; MORAIS, J.P.S.; PINTO, A.M.B.; AZEREDO, H.M.C. Fish gelatin films as affected by cellulose whiskers and sonication. Food Hydrocoll., v.41, p.113-118, 2014.

SANTOS, C.D.S. Biomimetical mineralization of chitosangelatin hydrogels. São Carlos, 2014. 100 p.[Dissertation of Master Degree. Chemistry Institute of São Carlos. University of São Paulo].

SATTURWAR, P.M.; MANDAOGADE, P.M.; FULZELE, S.V.; DARWHEKAR, G.N.; JOSHI, S.B.; DORLE, A.K. Synthesis and evaluation of rosin-based polymers as film coating materials. Drug Dev. Ind. Pharm., v.28, n.4, p.381$387,2002$.

SFORCIN, J.M.; BANKOVA, V. Propolis: is there a potential for the development of new drugs? J. Etnopharmacol., v.133, n.2, p.253-260, 2011.

SILVERSTEIN, R.M.; WEBSTER, F.X.; KIEMLE, D. Spectrometric identification of organic compounds. New York: Wiley, 2005. 512 p.

SOSKOLONE, W.A.; FREIDMAN, M.F. Intra-periodontal pocket drug delivery systems. In: RATHBONE, M.J. (Ed.). Oral mucosal drug delivery. Nova Iorque: Marcel Decker, 1996, v.74, p.359-379.

STEELE, T.W.J.; HUANG, C.L.; WIDJAJA, E.; BOEY, F.Y.C.; LOO, J.S.C.; VENKATRAMAN, S.S. The effect of polyethylene glycol structure on paclitaxel drug release and mechanical properties of PLGA thin films. Acta Biomater., v.7, n.5, p.1973-1983, 2011.

SULAIMAN, G.M.; AL SAMMARRAE, K.W.; AD'HIAH, A.H.; ZUCCHETTI, M.; FRAPOLI, R.; BELLO, E.; ERBA, E.; D'INCALCI, M.; BAGNATI, R. Chemical characterization of Iraqi propolis samples and assessing their antioxidant potentials. Food Chem. Toxicol., v.49, n.9, p.2415-2421, 2011. 
THAKUR, V.K.; THAKUR, M.K. Processing and characterization of natural cellulose fibers/thermoset polymer composites. Carbohydr. Polym., v.109, n.???, p.102-117, 2014.

VILLA NOVA, M.; GONÇALVES, M.C.P.; NOGUEIRA, N.A.; HERCULANO, L.S.; MEDINA, N.A.; BAZZOTE, R.B.; BRUSCHI, M.L. Formulation and characterization of ethylcellulose microparticles containing L-alanylL-glutamine peptide. Drug Dev. Ind. Pharm., v.40, n.10, p.1308-1317, 2014.

WENDLANDT, W.W. Thermal methods of analysis. 3ed. Nova York: Wiley, 1985. $524 \mathrm{p}$.
YANG, L.; PAULSON, A.T. Mechanical and water vapour barrier properties of edible gellan films. Food Res. Int., v.33, n.7, p.563-570, 2000.

YOO, J.W.; DHARMALA, K.; LEE, C.H. The physicodynamic properties of mucoadhesive polymeric films developed as female controlled drug delivery system. Int. J. Pharm., vv.309, n.1-2, p.139-145, 2006.

Received for publication on $17^{\text {th }}$ November 2014 Accepted for publication on $01^{\text {st }}$ September 2015 
